\title{
Primary intraocular chondrosarcoma in a dog
}

\author{
[Condrossarcoma intraocular primário em cão] \\ E. Perlmann ${ }^{1}$, A. Morales $^{2}$, A.C.A. Góes ${ }^{1}$, M.L.Z. Dagli ${ }^{1}$, P.S.M. Barros ${ }^{1}$ \\ ${ }^{1}$ Faculdade de Medicina Veterinária e Zootecnia - Universidade de São Paulo, São Paulo, SP \\ ${ }^{2}$ Universidade do Estado de São Paulo - Jaboticabal, SP
}

\begin{abstract}
A five-year-old male Cocker Spaniel was presented for evaluation of the right eye due to discomfort, abundant purulent discharge and progressive enlargement of the eyeball. The owner revealed that the right eye has appeared to be inflamed and smaller then the left eye for years. Ophthalmic examination revealed corneal perforation, buphthalmia and conjuctival hyperemia. Enucleating was performed due to signs of endophthalmitis and ocular discomfort. Histopathology revealed a multilobulated proliferation of chondrocytes producing hyaline cartilage with occasional pleomorphism and binucleate cells. A diagnosis of primary intraocular chondrosarcoma was done.
\end{abstract}

Keywords: chondrosarcoma, dog, intraocular neoplasia

\section{RESUMO}

Foi atendido um cão, da raça Cocker Spaniel, de cinco anos de idade, com desconforto ocular, secreção purulenta abundante e aumento progressivo do bulbo ocular. Ao exame oftálmico, evidenciaram-se perfuração corneana, buftalmia e hiperemia conjuntival. Foi realizada enucleação em decorrência do desconforto ocular intenso e dos sinais de endoftalmite. Exame histopatológico revelou proliferação multilobulada de condrócitos produzindo cartilagem hialina com pleomorfismo ocasional e células binucleadas. Foi diagnosticado condrossarcoma intraocular primário.

Palavras-chave: condrossarcoma, cão, neoplasia intraocular

\section{INTRODUCTION}

Chondrosarcoma is a malignant tumor characterized by the production of neoplastic chondrocytes in a fibrillary matrix (Popovitch et al., 1994). Histologically, chondrosarcomas can be divided into the more common myxoid type that is usually associated with the skeleton, and the less frequently diagnosed mesenchymal chondrosarcoma, which is more commonly found in extraskeletal locations (Casadei et al., 1991).

The extraskeletal forms of chondrosarcoma are extremely rare in dogs. In this report we describe the clinicopathologic findings of a primary intraocular chondrosarcoma in a five-year-old Cocker Spaniel.

\section{CASE REPORT}

A five-year-old, intact, male, Cocker Spaniel was presented for evaluation of the right eye due to discomfort, abundant purulent discharge and progressive enlargement of the eyeball. The owner reported that the right eye has appeared to be inflamed and smaller then the left eye for years, but had never been diagnosed or treated appropriately. Examination of the right eye revealed intense blepharospasm, buphthalmia, conjunctival hyperemia, abundant purulent discharge and corneal perforation. The right eye was clinically blind, lacking a menace response and indirect pupillary light reflex. There were no abnormalities in the left eye. Physical examination revealed no alterations, except body temperature of $39.9^{\circ} \mathrm{C}$. Enucleating was advised

Recebido em 9 de julho de 2012

Aceito em 10 de julho de 2013

E-mail: perlmann@ig.com.br 
based on the clinical signs of endophthalmitis. A complete blood count and serum chemistry panel was performed prior to surgery and revealed no important alterations, except for a mild neutrophilia. The eyeball was fixed in $10 \%$ buffered formalin, processed routinely for histological examination and sections were stained with H\&E and Gram's. In gross examination, a heterogenic firm yellow and white mass occupied almost the entire intraocular space (Figure 1). Histopathology showed a multilobulated proliferation of chondrocytes producing hyaline cartilage with occasional pleomorphism and binucleate cells (Figure 2). The tumor occupied most of the vitreous and anterior chamber (Figure 3). Frequent calcium deposits surrounded the cartilage tissue. Atypical mitosis was also present (Figure 4), but infrequent. An intense mononuclear (lymphocyte, plasma cells and macrophages) infiltration and fibrosis was present in the uvea, surrounding the cartilage matrix. Uveal tissue was identified through areas of heavily pigmented cells, but it was not possible to differentiate iris, ciliary body or choroid. The lens and the retina were not present in the sections. No scleral invasion by neoplastic tissue was identified. Neutrophils and bacteria were found in the tumor, probably due to corneal perforation. These findings were consistent with low-grade chondrosarcoma.

Skeletal and abdominal radiographs were taken to evaluate bone involvement and they were all normal. The absence of involvement of the bone or any other locations in the body indicates the eye was the primary site. After 2 years following surgery, the dog is in excellent general condition.

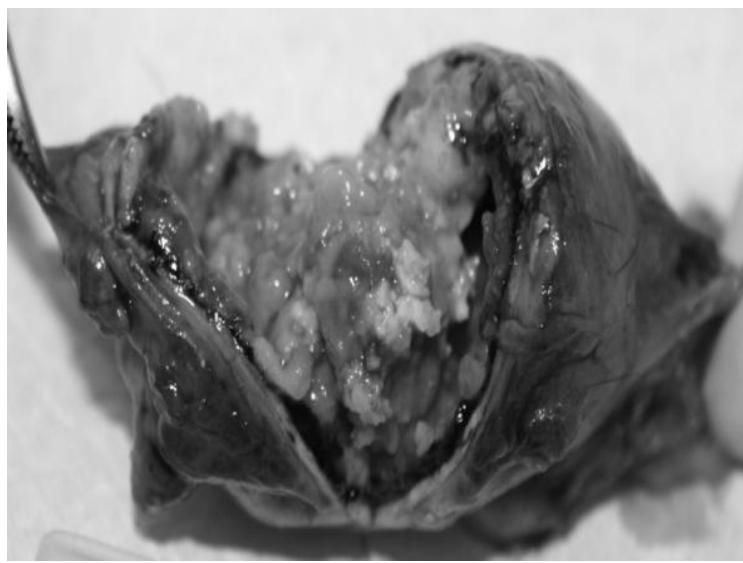

Figure. 1. Section of the eyeball; dog, a heterogenic firm yellow and white mass occupying almost the entire intraocular space.

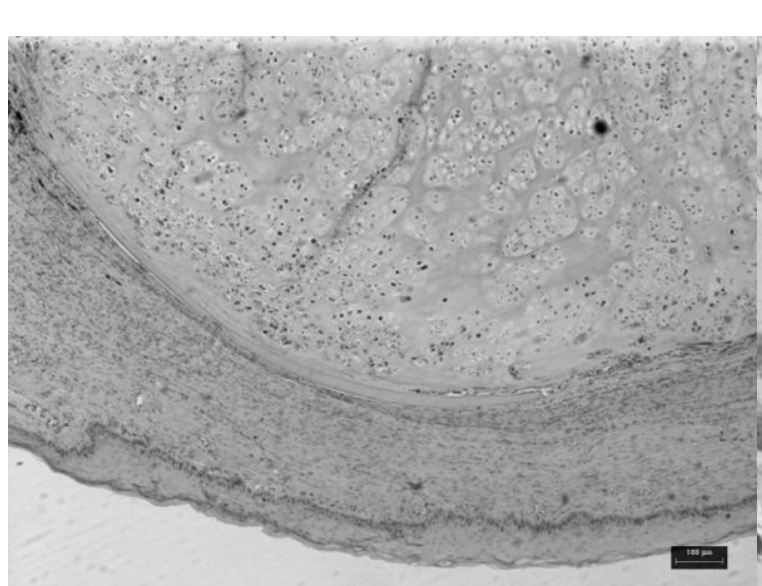

Figure. 3. Eye; dog, an extensive cartilage matrix with neoplastic chondrocytes occupying the anterior chamber. $\mathrm{H} \& \mathrm{E} . \mathrm{Bar}=100 \mu \mathrm{m}$.

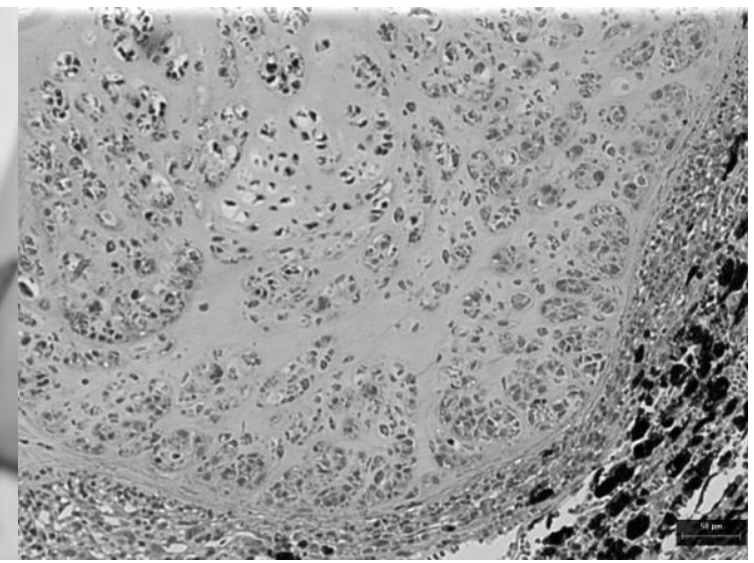

Figure. 2. Eye; dog, an intense mononuclear and fibroblasts infiltration in the uveal tissue surrounding a well demarcated area of cartilage matrix with neoplastic chondrocytes. H\&E. Bar $=50 \mu \mathrm{m}$.

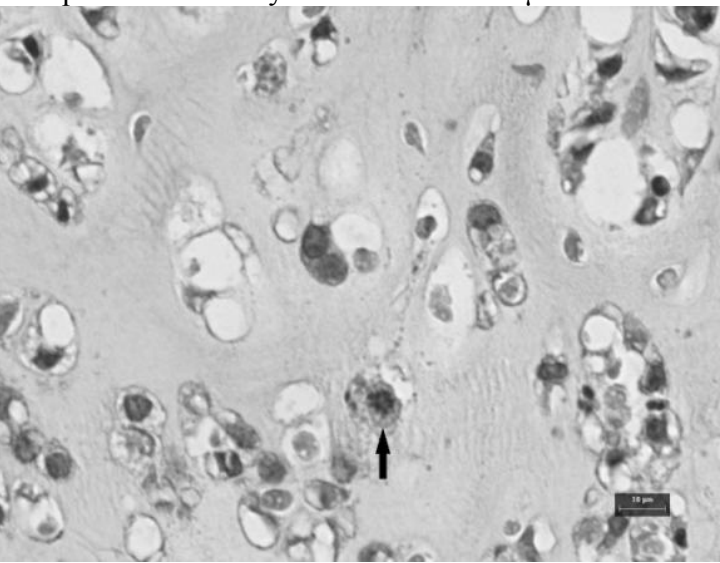

Figure 4. Eye; dog, a typical mitosis in a welldifferentiated chondroid area (arrow). H\&E. Bar = $10 \mu \mathrm{m}$. 


\section{DISCUSSION}

Although chondrosarcoma is the second most common bone neoplasia in both humans (Casadei et al., 1991) and dogs (Patnaik, 1990), it can originate outside the bone. Extraskeletal chondrosarcomas occur in the soft tissue or parenchymal organs, which lack preexisting cartilage (Patnaik, 1990; Casadei et al., 1991). The extraskeletal forms of chondrosarcoma are not common in dogs. They have been described in the bladder, heart, pericardium, right atrium, aorta, tongue, kidney, liver, abdominal wall, trachea, lungs, pulmonary artery, omentum, subcutaneous and mammary tissues, larynx, intestines and retroperitoneal space (Patnaik, 1990; Albers et al., 1997; Munday e Prahl, 2002; Davis and Holt, 2003; Mellanbay et al., 2003; Miller et al., 2005). Recently, three cases of primary intraocular extraskeletal chondrosarcoma were reported. The ages ranged from 10 to 15 years, with an average age of 11 years (Patnaik, 1990). The dog in the present report was considerably younger than those described in the literature. The occurrence of a primary intraocular osteosarcoma has also been reported (Heath et al., 2003). Osseous metaplasia in the eye is seen subject to chronic disease and trauma in the human, dogs, and cats (Heath et al., 2003; Lynch and Scagliotti, 2007). Intraocular cartilage metaplasia, not related with teratoid medulloepithelioma, has never been reported in dogs. In the present case, the dog presented a long history of chronic inflammation of unknown origins. Chronic inflammation can cause metaplasia (Lynch and Scagliotti, 2007) and latter neoplastic differentiation (Mundy and Dubielzig, 2008). Chronic intraocular inflammation is related with malignant mesenquimal neoplastic proliferation in cats (Dubielzig et al., 1990). Another theory is that these tumors may arise from primitive cartilage forming mesenchymal cells found throughout the body and that the development of the tumor occurs parallel to fetal chondrogenesis. Due to the lack of information about early changes and the extensive destruction of the intraocular architecture, its origin is unclear.

Primary intraocular chondrosarcomas are rare and, in the present case, may be related to chronic inflammation. Atrophic eyes (phthisis bulbi) or affected by chronic intraocular diseases in dogs should be monitored.

\section{REFERENCES}

ALBERS, T.M.; ALROY, J.; GARROD, L.A. et al. Histochemical and ultrastructural characterization of primary cardiac chondrosarcoma. Vet. Pathol., v.34, p.150-151, 1997.

CASADEI, R.; RICCI, M.; RUGGIERI, P. et al. Chondrosarcoma of the soft tissues: Two clinicopathologic study of 14 cases. Vet. Pathol., v.27, p.46-55, 1991

DAVIS, G.J.; HOLT, D. Two chondrosarcomas in the urethra of a German shepherd dog. J. Small Anim. Pract., v.44, p.169-171, 2003.

DUBIELZIG, R.R.; EVERITT, J.; SHADDUCK, J.A.; ALBERT, D.M. Clinical and morphologic features of post-traumatic ocular sarcomas in cats. Vet. Pathol, v.27, p.62-65, 1990.

HEATH, S.; RANKIN, A.J.; DUBIELZIG, R.R. Primary ocular osteosarcoma in a dog. Vet. Ophthalmol., v.6, p.85-87, 2003.

LYNCH, G.L.; SCAGLIOTTI, R.H. Osseous metaplasia in the eye of a dog. Vet. Pathol., v.44, p.222-224, 2007.

MELLANBAY, R.J.; HOLLOWAY, A.; WOODGER, $\mathrm{N}$. et al. Primary chondrosarcoma in the pulmonary artery of a dog. Vet. Radio \& Ultras., v.44, p.315-321, 2003.

MILLER, J.M.; WALSHAW, R.; BOURQUE, A.C. Primary splenic mesenchymal chondrosarcoma in a dog. Can. Vet. J., v.46, p.163-165, 2005.

MUNDAY, J.S.; PRAHL, A. Retroperitoneal extraskeletal mesenchymal chondrosarcoma in a dog. J. Vet. Diagn. Invest., v.14, p.498-500, 2002.

MUNDY, P.; DUBIELZIG, R.R. Primary intraocular osteosarcoma and chondrosarcoma in dogs. Vet. Ophthalmol., v.11, p.413-429, 2008.

PATNAIK, A.K. Canine extraskeletal osteosarcoma and chondrosarcoma: a different subgroups. J. of Bone and Joint Surg. - British, v.73-B, p.162-168, 1990.

POPOVITCH, C.A.; WEINSTEIN, M.J.; GOLDSCHMIDT, M.H. et al. Chondrosarcoma: a retrospective study of 97 dogs (1987-90). J. Am. Anim. Hosp. Ass., v.30, p.81-85, 1994. 